\title{
Conservative treatment of burst fractures of the thoracolumbar and lumbar spine
}

\author{
$\mathrm{H}$ Kinoshita MD,${ }^{1} \mathrm{Y}$ Nagata $\mathrm{MD},{ }^{1} \mathrm{H}$ Ueda $\mathrm{MD},{ }^{2} \mathrm{~K}$ Kishi $\mathrm{MD}^{3}$ \\ ${ }^{1}$ Director, Kosei Hospital, Hiroshima, Japan; ${ }^{2}$ Chugoku Rosai Hospital, Hiroshima, \\ Japan; ${ }^{3}$ Department of Orthopaedic Surgery, Hiroshima University School of Medicine, \\ Hiroshima, Japan.
}

Twenty-three patients with burst fracture of the thoracolumbar and lumbar spine were treated nonoperatively. Among these 23 patients, 13. had a neurological deficit and 10 patients did not have such a deficit.

Union of burst fractures occurred with conservative treatment in 22 out of 23 patients, but late operation was necessary in only one patient, who had an increasing kyphotic deformation.

Of the 13 patients with neurological deficit, 8 showed full recovery and none had neurological deterioration. It was observed by CT scans that the narrowing of the spinal canals was progressively relieved by natural remodelling of the fragments retropulsed into the spinal canal.

Keywords: burst fracture of thoracolumbar and lumbar spine; conservative treatment; follow up study; remodelling of fragments.

\section{Patients and methods}

By CT scans, 23 patients with a burst fracture of the thoracolumbar or lumbar spine were observed from 1981 to 1988 with vertebral bone fragments retropulsed into the spinal canal. The course of bone injuries of 10 cases without neurological deficit was observed by xray examinations and CT scans. A long term follow up was made using CT scans on the clinical course of paralysis, on the morphological changes of the vertebral bodies and on the spinal canals of 13 patients with a neurological deficit.

The series consisted of 11 males and 2 females in the age range 15-63 years (average 42.3 years). Of those 13 patients, 12 fell from a height and one was struck by a heavy object.

The fractured vertebral bodies were T12 in 2 patients, $\mathrm{L} 1$ in $6, \mathrm{~L} 2$ in 2, L3 in 1 and L4 in 2 patients.

The patients were treated by being flat on their bed for 8-10 weeks, and then being gradually mobilized while the spine was supported by a brace.

Sensory loss and notably sacral sparing

Correspondence: 86-2 Ichiida, Kurose-cho, Kamo-gun, Hiroshima-ken 724-06, Japan. were observed. Rectal and perianal sensation, voluntary anal sphincter control, anal wink, urinary sensation and voluntary voiding were periodically observed. Regarding motor paralysis, with the use of Daniels' muscle testing technique of manual examination, ${ }^{1}$ the functions of all the muscle groups controlling the hip, knee, ankle, and toes were evaluated and expressed as 5 (normal), 4 (good), 3 (fair), 2 (poor), 1 (trace), or 0.

Concerning the bony injury, the heights of the anterior and posterior aspect of the vertebral bodies were measured using conventional lateral view xray films, and the kyphotic angle was calculated by Cobb's method.

The area of the spinal canal and the bone fragments within the spinal canal were measured with a planimeter, and the degree of canal obstruction was expressed as a percentage.

\section{Results}

\section{Sensory changes}

In all of the patients, varying levels of anaesthesia, hypoaesthesia, and paraesthesia were observed below the inguinal region. 
At follow up, full recovery of sensory power was observed in 3 patients, with partial recovery in 9 . Hypoaesthesia of S1-2 in patient 3 recovered, but there was no change in anaesthesia of S3, 4, 5 .

Hypoaesthesia below L4 in the left leg of patient 11 recovered, but there was no change in anaesthesia below L4 of right leg (Table I).

\section{Motor paralysis}

There was no motor paralysis in patients 7, 9 and 12. Complete recovery from motor paralysis was observed during the follow up in patients $1,3,5,10$ and 13 with muscle strength restored to the normal level.

In patients 2, 4, 6 and 8 motor power controlling the foot has been partially restored, but as toe motion is impaired, these patients are walking with the use of one cane. In patient II, motor paralysis of the right knee, ankle and toes did not improve, but paralysis of the left knee and ankle improved and that patient has returned to work, walking with a right leg brace and one cane (Table I).

Recovery of neurological function was evaluated with the use of Frankel's scale (Table II). ${ }^{2}$ One patient improved from grade $\mathrm{C}$ to grade $\mathrm{D}$, and 5 from grade $\mathrm{D}$ to grade $\mathrm{E}$. In spite of the recovery made in motor and sensory functions in 4 patients, the improvement was not sufficient to advance into the next grade.

Muscles innervated by the spinal cord segment found at the time of the initial examination, with paraesthesiae or hypoaesthesia as sensory disorders all recovered. Of those whose muscle strength was 0 at the time of the initial examination, only patient 2 showed recovery, and patients 4,8 , and 11 did not show recovery. Recovery of motor function was observed up to the sixth month after injury; no significant recovery was observed after 6 months.

\section{Bladder paralysis}

At the time of the initial examination, urinary retention was observed in 7 patients, urinary sensation was restored in 6 with sacral sparing, within from 3 days to $4 \frac{1}{2}$ months after injury, and voluntary urination became possible. During the follow up, patient 4 continued to complain of urgency and incontinence, patient 5 of dysuria, and patient 6 of stress incontinence (Table III). Complete paralysis of bladder function persisted in only the following patient:-

Patient 3 is a 38 year old male who fell from a height sustaining a burst fracture of L1 vertebral body. At the time of the initial examination, hypoaesthesia of S1-2 segment, anaesthesia of S3-5, and toe weakness were observed. The Achilles tendon reflex and anal wink were absent. The sphincters were patulous and urinary sensation was absent. Motor function was completely restored 3 months later, and he could stand on his tiptoes. At the time of follow up made $6 \frac{1}{2}$ years later, the Achilles tendon reflex was restored, but the anal reflex was completely absent and recovery from bladder and bowel paralysis did not occur. The kyphotic angle which was $10^{\circ}$ at the time of initial examination was $8^{\circ} 5$ months later. Thereafter there was no change in the kyphotic angle nor in the height of the vertebral body. He complains of slight back pain, but no medication is necessary. This patient is now working in a steel works.

\section{Bone injury}

In all of the patients except one, bony union of the crushed vertebral body was completed within 4 months and the spinal column became stable.

The kyphotic angle of 13 patients with a neurological deficit averaged $12.4^{\circ}\left(0-30^{\circ}\right)$ at time of the initial examination, and was $3.2^{\circ}$ during bed rest. It was $6.6^{\circ}$ with the commencement of mobilisation with a brace, $9.2^{\circ} 6$ months thereafter, and $10.4^{\circ}$ one year later. No change was observed thereafter.

Bony fragments which had retropulsed into the spinal canal occupied $55 \%-29.2 \%$ of the spinal canal.

No correlation could be demonstrated between the degree of spinal canal compromise as measured by CT scans and the resulting neurological disturbance. 
Table I Degree of spinal compromise and neurological function at admission and at follow up

\begin{tabular}{|c|c|c|c|c|c|c|c|c|c|c|c|c|c|c|c|}
\hline Subject & $\begin{array}{l}\text { Age/ } \\
\text { Sex }\end{array}$ & $\begin{array}{l}\text { Site of } \\
\text { injury }\end{array}$ & \multicolumn{2}{|c|}{$\begin{array}{c}\text { Spinal canal } \\
\text { compromise } \\
\text { Admission Follow up }\end{array}$} & $\begin{array}{l}\text { Sensory loss } \\
\text { at admission }\end{array}$ & \multicolumn{3}{|c|}{$\begin{array}{l}\text { Motor paralysis } \\
\text { at admission }\end{array}$} & $\begin{array}{l}\text { Sensory } \\
\text { recovery }\end{array}$ & \multicolumn{3}{|c|}{$\begin{array}{l}\text { Motor recovery } \\
\text { at follow up }\end{array}$} & $\begin{array}{l}\text { Back } \\
\text { pain }\end{array}$ & $\begin{array}{l}\text { Frankel's } \\
\text { scale }\end{array}$ & Walking \\
\hline 1 & $60 / \mathrm{M}$ & $\mathrm{T} 12$ & $33.9 \%$ & $0 \%$ & $\begin{array}{l}\text { Bilateral } \\
\text { Below L4 } \\
\text { Hyp }\end{array}$ & $\begin{array}{l}\text { Ankle } \\
\text { Toe }\end{array}$ & $\begin{array}{l}\mathrm{R} \\
3 \\
2\end{array}$ & $\begin{array}{l}\mathrm{L} \\
3 \\
2\end{array}$ & Full & Full & $\mathrm{R}$ & $\mathrm{L}$ & + & $\mathrm{D}-\mathrm{E}$ & \\
\hline 2 & $49 / \mathrm{M}$ & $\mathrm{T} 12$ & $41.2 \%$ & $9.9 \%$ & $\begin{array}{l}\text { Bilateral below } \\
\text { L1 parae } \\
\text { L5 hyp }\end{array}$ & $\begin{array}{l}\text { Knee } \\
\text { Ankle } \\
\text { Toe }\end{array}$ & $\begin{array}{l}3 \\
0 \\
0\end{array}$ & $\begin{array}{l}2 \\
0 \\
0\end{array}$ & Full & $\begin{array}{l}\text { Knee } \\
\text { Ankle } \\
\text { Toe }\end{array}$ & $\begin{array}{l}3 \\
1 \\
0\end{array}$ & $\begin{array}{l}4 \\
3 \\
3\end{array}$ & & D-D & Cane \\
\hline 3 & $38 / \mathrm{M}$ & L11 & $36.0 \%$ & $15.0 \%$ & $\begin{array}{l}\text { Bilateral } \\
\text { S1-2 hyp } \\
\text { S3-5 anae }\end{array}$ & $\begin{array}{l}\text { Ankle } \\
\text { Toe }\end{array}$ & $\begin{array}{l}5 \\
2\end{array}$ & $\begin{array}{l}5 \\
2\end{array}$ & $\begin{array}{l}\text { S1-2 full } \\
\text { S3-5 no change }\end{array}$ & Full & & & + & $\mathrm{D}-\mathrm{E}$ & \\
\hline 4 & $43 / \mathrm{M}$ & L1 & $33.6 \%$ & $15.2 \%$ & $\begin{array}{l}\text { Bilateral below } \\
\text { L1 hyp }\end{array}$ & $\begin{array}{l}\text { Knee } \\
\text { Ankle } \\
\text { Toe }\end{array}$ & $\begin{array}{l}3 \\
3 \\
0\end{array}$ & $\begin{array}{l}3 \\
0 \\
0\end{array}$ & Improve & $\begin{array}{l}\text { Knee } \\
\text { Ankle } \\
\text { Toe }\end{array}$ & $\begin{array}{l}4 \\
3 \\
0\end{array}$ & $\begin{array}{l}4 \\
0 \\
0\end{array}$ & & D-D & Cane \\
\hline 5 & $15 / \mathrm{F}$ & L1 & $41.3 \%$ & $21.0 \%$ & $\begin{array}{l}\text { Bilateral below } \\
\text { L1 hyp }\end{array}$ & $\begin{array}{l}\text { Ankle } \\
\text { Toe }\end{array}$ & $\begin{array}{l}3 \\
3\end{array}$ & $\begin{array}{l}3 \\
3\end{array}$ & Improve & Full & & & + & D-E & \\
\hline 6 & $63 / \mathrm{F}$ & L1 & $37.3 \%$ & $0 \%$ & $\begin{array}{l}\text { Bilateral below } \\
\text { L5 hyp }\end{array}$ & $\begin{array}{l}\text { Hip } \\
\text { Knee } \\
\text { Ankle } \\
\text { Toe }\end{array}$ & $\begin{array}{l}2 \\
1 \\
0 \\
0\end{array}$ & $\begin{array}{l}2 \\
1 \\
1 \\
0\end{array}$ & Improve & $\begin{array}{l}\text { Hip } \\
\text { Knee } \\
\text { Ankle } \\
\text { Toe }\end{array}$ & $\begin{array}{l}4 \\
2 \\
0 \\
0\end{array}$ & $\begin{array}{l}4 \\
2 \\
1 \\
0\end{array}$ & & D-D & Cane \\
\hline 7 & $24 / M$ & L1 & $50.4 \%$ & $7.4 \%$ & $\begin{array}{l}\text { Bilateral only } \\
\text { L4L5 hyp }\end{array}$ & - & & & Improve & No det & orati & & & $E-E$ & \\
\hline 8 & $49 / M$ & L1 & $37.3 \%$ & $0 \%$ & $\begin{array}{l}\text { Bilateral below } \\
\text { L4 hyp }\end{array}$ & $\begin{array}{l}\text { Knee } \\
\text { Ankle } \\
\text { Toe }\end{array}$ & $\begin{array}{l}3 \\
0 \\
0\end{array}$ & $\begin{array}{l}3 \\
0 \\
0\end{array}$ & Improve & $\begin{array}{l}\text { Knee } \\
\text { Ankle } \\
\text { Toe }\end{array}$ & $\begin{array}{l}4 \\
0 \\
0\end{array}$ & $\begin{array}{l}4 \\
0 \\
0\end{array}$ & & D-D & Cane \\
\hline 9 & $60 / M$ & $\mathrm{~L} 2$ & $29.2 \%$ & $10.0 \%$ & $\begin{array}{l}\mathrm{R} \text { below L2 hyp } \\
\mathrm{L}-\end{array}$ & - & & & Improve & No det & orati & & + & E-E & \\
\hline
\end{tabular}


Table I (cont)

\begin{tabular}{|c|c|c|c|c|c|c|c|c|c|c|c|c|c|c|c|}
\hline \multirow{2}{*}{$\begin{array}{l}\text { Subject } \\
10\end{array}$} & \multirow{2}{*}{$\begin{array}{l}\begin{array}{l}\text { Age/ } \\
\text { Sex }\end{array} \\
24 / M\end{array}$} & \multirow{2}{*}{$\frac{\begin{array}{c}\text { Site of } \\
\text { injury }\end{array}}{\text { L2 }}$} & \multicolumn{2}{|c|}{$\begin{array}{c}\text { Spinal canal } \\
\text { compromise } \\
\text { Admission Follow up }\end{array}$} & \multirow{2}{*}{$\begin{array}{l}\begin{array}{l}\text { Sensory loss } \\
\text { at admission }\end{array} \\
\begin{array}{l}\mathrm{R}- \\
\text { L below L3 hyp }\end{array}\end{array}$} & \multicolumn{3}{|c|}{$\begin{array}{l}\text { Motor paralysis } \\
\text { at admission }\end{array}$} & \multirow{2}{*}{$\begin{array}{l}\text { Sensory } \\
\text { recovery }\end{array}$} & \multicolumn{3}{|c|}{$\begin{array}{l}\text { Motor recovery } \\
\text { at follow up }\end{array}$} & \multirow[t]{2}{*}{$\begin{array}{l}\text { Back } \\
\text { pain }\end{array}$} & \multirow{2}{*}{$\begin{array}{c}\begin{array}{c}\text { Frankel's } \\
\text { scale }\end{array} \\
\text { D-E }\end{array}$} & \multirow[t]{2}{*}{ Walking } \\
\hline & & & $0 \%$ & $0 \%$ & & $\begin{array}{l}\text { Ankle } \\
\text { Toe }\end{array}$ & - & $\begin{array}{l}3 \\
2\end{array}$ & & Full & & & & & \\
\hline 11 & 45/M & L3 & $55.0 \%$ & $12.2 \%$ & $\begin{array}{l}\mathrm{R} \text { below } \mathrm{L} 4 \text { anae } \\
\mathrm{L} \text { below } \mathrm{L} 4 \text { hyp }\end{array}$ & $\begin{array}{l}\text { eHip } \\
\text { Knee } \\
\text { Ankle } \\
\text { Toe }\end{array}$ & $\begin{array}{l}3 \\
0 \\
0 \\
0\end{array}$ & $\begin{array}{l}3 \\
3 \\
2 \\
2\end{array}$ & $\begin{array}{l}\mathrm{R} \text { no change } \\
\mathrm{L} \text { improve }\end{array}$ & $\begin{array}{l}\text { Hip } \\
\text { Knee } \\
\text { Ankle } \\
\text { Toe }\end{array}$ & $\begin{array}{l}4 \\
0 \\
0 \\
0\end{array}$ & $\begin{array}{l}4 \\
4 \\
4 \\
4\end{array}$ & + & $\mathrm{C}-\mathrm{D}$ & $\begin{array}{l}\text { Cane } \\
\text { Orthosis }\end{array}$ \\
\hline 12 & 27/M & L4 & $49.5 \%$ & $13.3 \%$ & $\begin{array}{l}\mathrm{R}- \\
\mathrm{L} \text { below L4 hyp }\end{array}$ & - & & & Improve & No det & orati & & & $E-E$ & \\
\hline 13 & 53/M & $\mathrm{L} 4$ & $46.2 \%$ & $14.6 \%$ & $\begin{array}{l}\text { Bilateral } \\
\text { Below L4 hyp }\end{array}$ & $\begin{array}{l}\text { Ankle } \\
\text { Toe }\end{array}$ & $\begin{array}{l}2 \\
1\end{array}$ & $\begin{array}{l}2 \\
1\end{array}$ & Improve & Full & & & + & $\mathrm{D}-\mathrm{E}$ & \\
\hline
\end{tabular}

Hyp $=$ hypaesthesia, parae $=$ paraesthesia, anae $=$ anaesthesia, $-=$ negative, improve $=$ improvement, $\mathrm{R}=$ right, $\mathrm{L}=$ left. 
Table II Neurological function at admission and follow up

\begin{tabular}{lccccc}
\hline & \multicolumn{5}{c}{ Follow up examination } \\
Initial & & & & \\
examination & A & B & C & D & E \\
\hline A & & & & & \\
B & & & & & \\
C & & & & 1 & \\
D & & & & 4 & 5 \\
E & & & & 3 \\
\hline
\end{tabular}

With time there was a spontaneous remodelling of the bone fragments retropulsed into the spinal canal, and the bone fragments decreased to one-half in size 12 months after the injury. In 3 patients $(6,8$, and 10), the spinal canal has become anatomically normal $4 \frac{1}{2}$ years thereafter. Though recovery of the neural deficit could not be observed after 6 months, remodelling of bone fragments progressed thereafter (Figs 1, 2, 3).

Increased kyphosis aggravated during conservative treatment occured in one patient and operative treatment was necessary:-

A 42 year old female hospitalised for schizophrenia jumped from the third floor to a two-storied rooftop in a suicide attempt and sustained a comminuted fracture of the left humeral head and a burst fracture of L1.
The height of the anterior margin of L1 vertebral body decreased by half and kyphosis of $29^{\circ}$ was observed (Fig 4a). The spinal canal was found to be completely obstructed as seen in the CT scan, but there was no neurological deficit (Fig 4b).

For a humerus fracture, fixation by open reduction and multiple wiring was made, and for burst fracture, fixation was by body cast. However, the patient could not understand her physician's instructions and 2 weeks later she began to wander about. Kyphosis gradually increased and it reached $45^{\circ}$ after 3 months (Fig 4c). There was no paralysis and 4 months later she was discharged at her own request. One month after discharge back pain became so severe that she could not do any housework and she was readmitted. Two weeks later fixation by open reduction and a pedicle screw was made and external fixation was added by body cast (Fig 4d). There was no postoperative paralysis. One month later firm fixation was made by renewing the body cast, and gait training was initiated.

\section{Complications}

During conservative treatment, one patient developed a neurological deficit:-

Patient 10, a 24 year old male, fell from a height of $2.5 \mathrm{~m}$ and had immediate pain in his back. Xrays revealed a burst fracture of L2 with a kyphotic angle of $12^{\circ}$. A CT scan

Table III Bladder paralysis

\begin{tabular}{lcccll}
\hline Subject & $\begin{array}{c}\text { Level of } \\
\text { lesion }\end{array}$ & $\begin{array}{c}\text { Sacral } \\
\text { sparing }\end{array}$ & $\begin{array}{c}\text { Urinary } \\
\text { sensation }\end{array}$ & $\begin{array}{l}\text { Appearance } \\
\text { of urgency of } \\
\text { micturition }\end{array}$ & $\begin{array}{l}\text { Bladder function } \\
\text { at follow up }\end{array}$ \\
\hline 1 & T12 & + & + & & Normal \\
2 & T12 & + & - & 3 days & Normal \\
3 & L1 & - & - & - & Urinary retention \\
4 & L1 & + & - & 4.5 months & Urge incontinence \\
5 & L1 & + & - & 1.5 months & Dysuria \\
6 & L1 & + & - & 4 weeks & Stress incontinence \\
7 & L1 & + & + & 5 weeks & Normal \\
8 & L1 & + & - & 5 Normal \\
9 & L2 & + & + & & Normal \\
10 & L2 & + & + & & Normal \\
11 & L3 & + & - & 6 weeks & Normal \\
12 & L4 & + & + & & Normal \\
13 & L4 & + & + & & \\
\hline
\end{tabular}




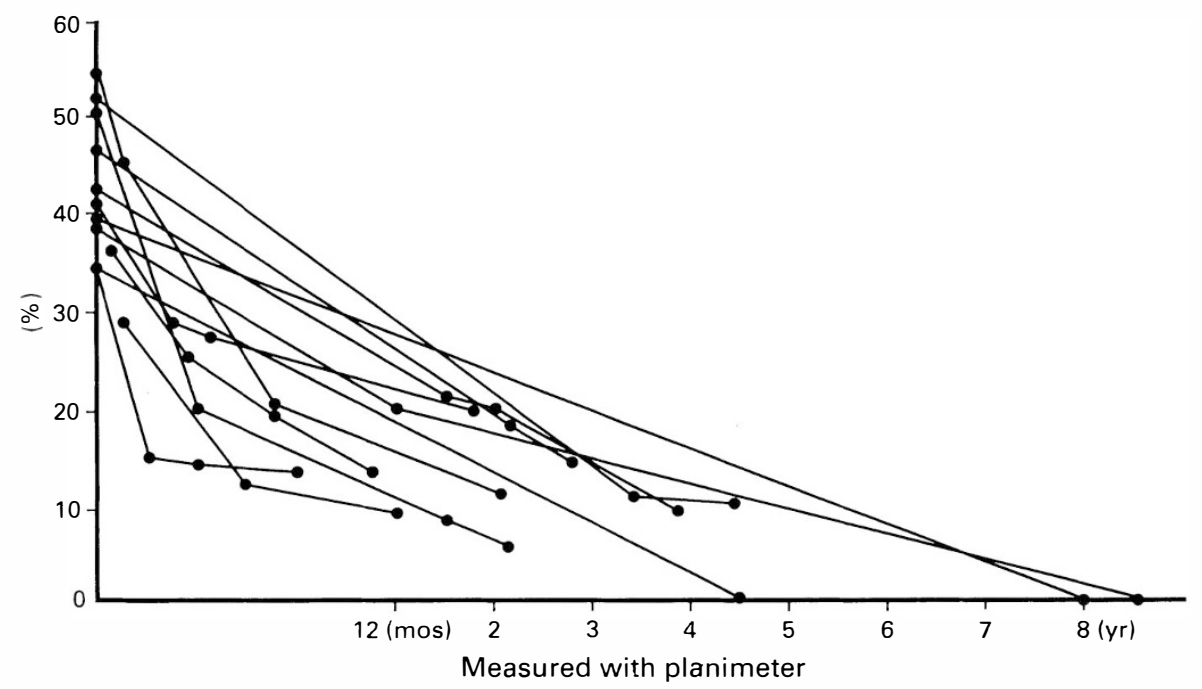

Figure 1 Remodelling of bony fragment. Bony fragment into the spinal canal determined with planimeter (expressed as ratio of bony fragment to the spinal canal).

a

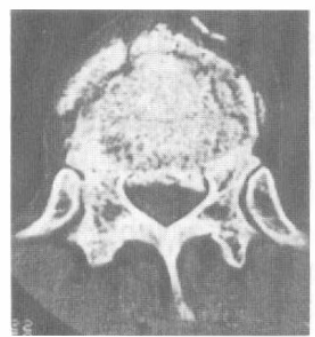

b

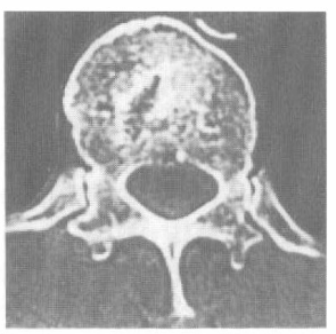

Figure 2 Patient 1. 60 year old male with burst fracture of T12 with neurological deficit. (a) Ratio of bony fragment to the original spinal canal (RBO) $33.9 \%$ at the time of injury. (b) RBO $0 \% 4 \frac{1}{2}$ years after injury.

of the injury site showed a fracture of the posterior wall, but no bony fragment was retropulsed into the spinal canal. He had no neurological deficit. After 3 days in a sitting position in an extension body cast, he complained of numbness and weakness in the left leg. Physical examination revealed hypoaesthesia of the left L3-4 segment and weakness of the anterior tibial muscle and extensor toe muscle.

The cast was immediately removed and after one week of strict bed rest numbness and weakness were alleviated. There was a a

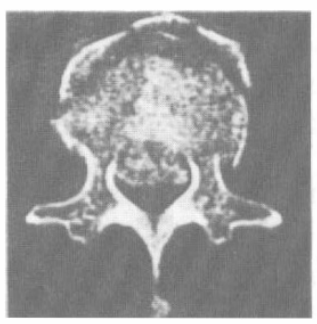

c

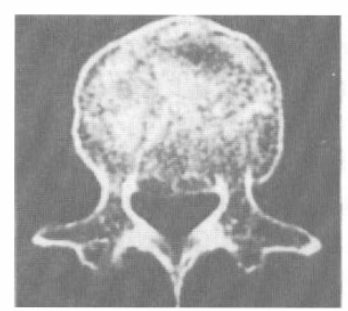

b

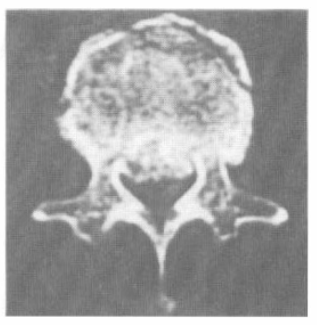

d

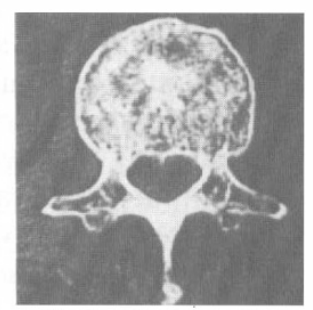

Figure 362 year old female with burst fracture of L2 without neurological deficit. (a) RBO $53.9 \%$ at the time of injury. (b) RBO $47.8 \%$ isolated bone fragment has begun to unite with vertebral body 7 weeks after injury. (c) RBO $21 \% 7$ months after injury. (d) RBO $3.4 \% \quad 1$ year 7 months after injury.

complete recovery 2 weeks later, and on the 91 st day after injury he was discharged. At the time of his last visit 3 years and 8 months 
a

b

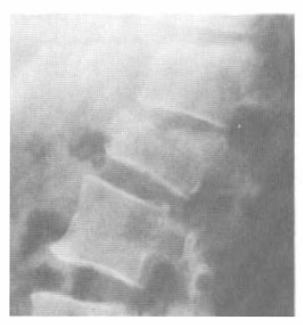

c

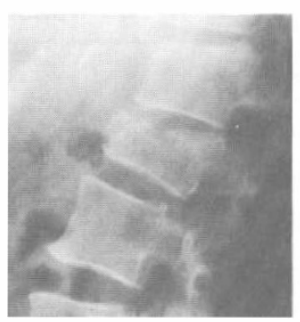

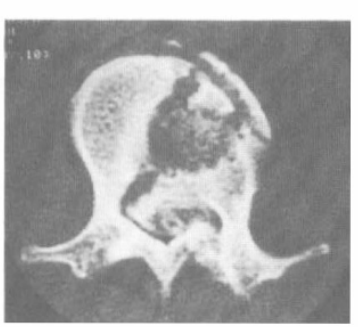

d

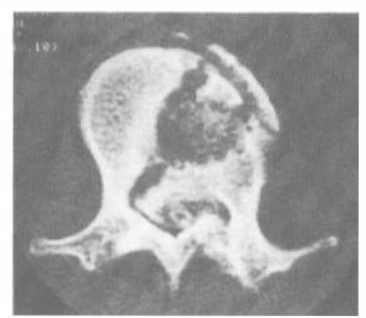

Figure 442 year old male with burst fracture of L2. (a) Kyphotic angle $29^{\circ}$ at the time of initial examination. (b) CT scan showed severe spinal canal compromise without neurological deficit. (c) Kyphotic angle $45^{\circ} 3$ months later. (d) Open reduction and pedicle screw fixation $5 \frac{1}{2}$ months later.

thereafter, there was no neurological deficit, back pain was absent, and he was working.

Thrombosis of the deep veins is extremely rare in the Japanese and none was observed in the present series. There were no instances of delayed union or pseudoarthrosis. Five patients complained of back pain, but -medication had not been necessary.

Patient 11 was seen elsewhere with a complaint of unbearable anaesthesia dolorosa of the completely paralysed right leg. A laminectomy was performed but without any beneficial effect.

\section{Discussion}

The optimal treatment of burst fracture is one of the most controversial topics in spinal reconstructive surgery. ${ }^{3}$ Surgical enthusiasm has been rekindled by the application of Harrington distraction rod fixation which achieves and maintains anatomical realignment. $^{4}$

The advent of computed tomography

(CT) scanners, and the availability of high resolution cross section images of the spinal canal have provided a new mode of investigating fractures of the spine and their effects on the size of the spinal canal, the resulting neural deficit, and the results of surgically designed procedures to restore the canal to normal anatomical dimensions. ${ }^{5}$ Thus, the treatment of thoracolumbar and lumbar burst fractures is in a state of rapid development with emphasis on operative decompression, stabilisation, and early mobilisation which in turn reduce medical complications and prevent late deformity and late neurological deficit. These would also reduce the length of initial hospitalisation, resulting in reduced medical cost. Operative intervention has gained the greatest support. $^{5-26}$

Denis, ${ }^{8}$ Jacobs, ${ }^{26}$ Kaneda, ${ }^{15}$ McAfee,${ }^{17}$ McEvoy, ${ }^{3}$ and Zawadzski ${ }^{25}$ have shown that surgical intervention gives better neurological results.

We have compared the neurological results of our patients with those of McAfee and Kaneda. McAfee et al ${ }^{17}$ treated burst fractures of the thoracolumbar junction with posterolateral decompression and Harrington rod instrumentation. Nine $(75 \%)$ of the 12 patients with incomplete paralysis improved sufficiently to enter the next Frankel subgroup, with 4 patients of Frankel E showing no neurological deterioration.

Kaneda et al $^{15}$ treated 27 patients with burst fractures of the thoracolumbar and lumbar spine with neurological deficit by anterior decompression and stabilisation with Zielke instrumentation or with their newly designed anterior instrumentation. One patient in Frankel A did not have neurological improvement. Nineteen (73\%) out of the 26 patients with incomplete paralysis entered the next Frankel subgroup.

The authors treated burst fractures of the thoracolumbar and lumbar spine with bed rest. Six $(60 \%)$ out of 10 patients with incomplete paralysis entered the next Frankel subgroup. Three in Frankel E grade had no neurological deterioration. Concerning recovery of conus medullaris lesions: 5 $(62.5 \%)$ out of 8 patients had full recovery in McAfee's; series: and $5(72.5 \%)$ out of 8 
patients had complete recovery in Kaneda's series.

In our series, one patient with a complete conus medullaris lesion did not recover. All $6(100 \%)$ patients with sacral sparing achieved voluntary urinary bladder control, but 3 patients continued to have urgent incontinence, stress incontinence, or dysuria. The recovery rate in our patients was slightly lower than in those reported by McAfee and Kaneda.

Of the 56 patients in the foregoing 3 groups, 1 patient belonged to grade $\mathrm{A}, 2$ to grade $\mathrm{B}, 1$ to grade $\mathrm{C}$, and $52(93 \%)$ to grades $\mathrm{D}$ and $\mathrm{E}$. Neurological deficit due to burst fracture was slight in most of the patients, and even with conservative treatment the neurological deficit completely recovered in $60 \%$ of the patients.

We should be mindful that reports on the results of operative treatment actually give the results of operative treatment superimposed on naturally occurring neural recovery. ${ }^{27}$

A large number of authors had reported that no difference in the amount of neurological recovery could be detected between operatively treated patients and conservatively treated patients. ${ }^{4,5,10,17,20,22,27-31}$

Willén et $a l^{23}$ have reported that though Jacobs, Soreff, and Dickson amongst others have had the impression that acute spinal surgery with Harrington rods will improve neurological restitution, this has not been proven.

According to Ferguson et al, ${ }^{29}$ the reports made by Larson, Dunn and Bradford on improved neurological recovery after anterior decompression of the neural canal with middle element encroachment are equivocal. Whitesides ${ }^{32}$ has reported that complete injury to the conus will never recover, neuropraxia will recover rapidly, axonotmesis will recover slowly and possibly incompletely due to the long length of some of the axons, and neurotmesis will never recover.

In the present study, motor paralysis in patient 11 did not recover. It was considered that this patient's paralysis was due to neurotmesis because both sensory loss and motor paralysis were complete at the time of the initial examination. It is possible that the paralysis in patients $2,4,6$ and 8 might be axonotmesis because of sensory incomplete loss and motor complete paralysis. Only motor paralysis of patient 2 recovered, but that in patients 2,4 and 8 did not. If the motor paralysis of these 3 patients and the incomplete bladder function of the 3 patients with sacral sparing had recovered more efficiently by decompression of the neural element, the effect of operative treatment could be confirmed.

It is essential to conduct a meticulous and accurate neurological examination at regular intervals to assess the effects of decompression therapy. The neurological symptoms before and after surgery have rarely been described, though a thorough neurological examination must be done and be recorded.

Ninety percent of fractures of the spine will heal spontaneously. If bed rest is continued long enough, almost all fractures of the spine will become stable..$^{2,10,29,33}$ In the present series, bony union of thoracolumbar and lumbar burst fractures occurred conservatively in 22 out of 23 patients with only one case requiring late operation.

The narrowing of the spinal canal observed by CT scans is progressively relieved by natural remodelling. ${ }^{34}$ In this study, bone fragments retropulsed into the spinal canal were reduced in size in time and became about one-half in size within 12 months after the injury. Denis ${ }^{8}$ has reported that obstruction greater than $75 \%$ of the canal cross section is accompanied by neurological damage (Frankel B for the conus group and Frankel $\mathrm{C}$ for the cauda equina group). Patients with obstruction of the spinal canal by $25-50 \%$ rarely present with neurological damage in the cauda equina group.

Hashimoto et al ${ }^{35}$ have shown that though there is no direct correlation between spinal canal stenosis and neurological status, there is a degree of compromise when neurological injury becomes probable. Kaneda ${ }^{15}$ and McEvoy ${ }^{3}$ have shown clinically that patients with neurological injury have a better chance of improvement by surgical treatment than by nonoperative treatment. In our patients, there was no correlation between the degree of canal compromise and neurological deficit. 
Many authors have observed a poor correlation between the degree of canal compromise and the resulting neurological deficit. $^{5,14,17,18,28}$ Some authors have reported that osseous protrusion into the spinal canal combined with increasing kyphotic deformity causes some neurological problem after nonoperative treatment. ${ }^{6,7,9,12,16,36}$ In this 2-10 year follow up, bone fragments in the spinal canal progressively decreased in size with time by natural remodelling and almost disappeared by 5 years after injury. We do not anticipate the onset of late symptomatic spinal stenosis or late paralysis. Reid ${ }^{18}$ has emphasised that if neurological deterioration should occur, the chances of improving the situation with late decompression are good.

The average period of hospitalisation of our patients was 114 days. Early surgical realignment and stabilisation permit early mobilisation and reduce the length of initial hospitalisation. However, this is a major procedure with operative risks and significant complications. ${ }^{4,31}$

It must be remembered that perfectly satisfactory results can result from conservative management. Operative treatment is necessary for patients with a progressive kyphotic deformity who are so irritable and restless that they cannot be properly controlled.

\section{References}

1 Daniels MA, Worthingham C (1972) Muscle testing techniques of manual examination. WB Saunders Company, Philadelphia, London, Toronto.

2 Frankel HL, Hancock DO, Melzak LS, Ungar GH, Vernon JD, Walsh JJ (1969) The value of postural reduction in the initial management of closed injuries of the spine with paraplegia and tetraplegia. Part 1. Paraplegia 7: 179-192.

3 McEvoy RD, Bradford DS (1985) The management of burst fractures of the thoracic and lumbar spine. Experience in 52 patients. Spine 10: 631-637.

4 Davis WE, Morris JH, Hill V (1980) An analysis of conservative (non-surgical) management of thoracolumbar fractures and fracture-dislocations with neural damage. J Bone Joint Surg 62 A: 1324-1328.

5 Durward QJ, Schweigel JF, Harrison P (1981) Management of fractures of the thoracolumbar and lumbar spine. Neurosurgery 8: 555-561.

6 Bohlman HH (1976) Late, progressive paralysis and pain following fractures of the thoracolumbar spine. $J$ Bone Joint Surg 58A: 728.

7 Bohlman HH (1985) Treatment of fractures and dislocations of the thoracic and lumbar spine. J Bone Joint Surg 67 A: $165-169$.

8 Denis F (1983) The three column spine and its significance in the classification of acute thoracolumbar spine injuries. Spine 8: 817-831.

9 Denis F, Searls K, Matta L (1984) Acute thoracolumbar burst fractures in the absence of neurologic deficit. Clin Orthop Rel Res 189: 142-149.

10 Dickson JH, Harrington PR, Erwin WD (1978) Results of reduction and stabilization of the severely fractured thoracolumbar and lumbar spine. J Bone Joint Surg 60A: 795-805.

11 Erickson DL, Leider LL, Brown WE (1977) One stage decompression-stabilization for thoracolumbar fractures. Spine 2: 53-59.

12 Esses SI, Botsford DJ, Kostuik JP (1990) Evaluation of surgical treatment for burst fractures. Spine 15: 667-673.

13 Flesch JR, Leider LL, Erickson DL, Chou SN, Bradford DS (1977) Harrington instrumentation and spine fusion for unstable fractures and fracture dislocations of the thoracic and lumbar spine. J Bone Joint Surg 59A: 143-153.

14 Gertzbein SD, Macmichel D, Tile M (1982) Harrington instrumentation as a method of fixation in fractures of the spine. J Bone Joint Surg 64B: 526-529.

15 Kaneda K, Abumi K, Fujita M (1984) Burst fractures with neurological deficits of the thoracolumbar-lumbar spine. Results of anterior decompression and stabilization with anterior instrumentation. Spine 9: 788-795.

16 Kostuik JP, Matsusaki H (1989) Anterior stabilization, instrumentation, and compression for post-traumatic kyphosis. Spine 14: 379-385.

17 McAfee PC, Yuan HA, Lasda NA (1982) The unstable burst fracture. Spine 7: 365-373.

18 Reid DC, Ch M, Hu R, Davis LA, Saboe LA (1988) The non-operative treatment of burst fractures of the thoracolumbar junction. J Trauma 28: 1188-1194.

19 Sullivan JA (1984) Sublaminal wiring of Harrington distraction rod for unstable thoracolumar spine fractures. Clin Orthop Rel Res 189: 178-185. 
20 Weinstein JN, Collarts DP, Lehmann TR (1988) Thoracolumbar 'burst' fractures treated conservatively: A long term follow-up. Spine 13: 33-38.

21 Whitesides TE, Alishah SG (1976) On the management of unstable fractures of the thoracolumbar spine. Rationale for use of anterior decompression and fusion and posterior stabilization. Spine 1: 99-107.

22 Willén J, Lindahl S, Irtam L, Nordwall A (1984) Unstable thoracolumbar fractures. A study by CT and conventional rentogenology of the reduction effect of Harrington instrumentation. Spine 9: 214-219.

23 Willen J, Lindahl S, Nordwall A (1985) Unstable thoracolumbar fractures. A comparative clinical study of conservative treatment and Harrington instrumentation. Spine 10: 111-122.

24 Yosipovitch Z, Robin GC, Makin M (1977) Open reduction of unstable lumbar spinal injuries and fixation with Harrington rods. J Bone Joint Surg 59A: 1003-1015.

25 Zawadzki MB, Jeffery RB, Mi, Minagi H, Pitts LH (1982) High resolution CT of thoracolumbar fracture. AJNR 3: 69-74.

26 Jacobs RR, Asher MA, Snider RK (1988) Thoracolumbar spinal injuries. A comparative study of recumbent and operative treatment in 100 patients. Spine 5: 463-477.

27 Young JS, Dexter WR (1987) Neurological recovery distal to the zone of injury on 172 cases of closed traumatic spinal cord injury. Paraplegia 16: 39-49.

28 Dall BE, Stauffer ES (1988) Neurologic injury and recovery patterns in burst fractures at the T12 or L1 motion segment. Clin Orthop Rel Res 233: 171-176.

29 Ferguson RL, Allen BL (1984) A mechanistic classification of thoracolumbar spine fractures. Clin Orthop Rel Res 189: 77-88.

30 Lewis J, McKibbin B (1978) The treatment of unstable fracture-dislocations of the thoracolumbar spine accompanied by paraplegia. J Bone Joint Surg 56B: 603-612.

31 Osebold WR, Weinstein SL, Sprange B (1981) Thoracolumbar spine fractures. Results of treatment. Spine 6: 13-34.

32 Whitesides TE (1977) Traumatic kyphosis of the thoracolumbar spine. Clin Orthop Rel Res 128: 78-92.

33 Bedbrook GM (1985) A balanced viewpoint in the early management of patients with spinal injuries who have neurological damage. Paraplegia 23: 8-15.

34 Fidler MW (1988) Remodelling of the spinal canal after burst fracture. J Bone Joint Surg 70B: 730-732.

35 Hashimoto Y, Kaneda K, Abumi K (1988) Relationship between traumatic spinal canal stenosis and neurologic deficits in thoracolumbar fractures. Spine 13: 268-1272.

36 Nash CL, Schatzinger LH, Brown RH, Brockey J (1977) The unstable stable thoracic compression fracture. Its problems and the use of spinal cord monitoring in the evaluation of treatment. Spine 2: 261-265. 